\title{
METHODS FOR DETERMINING THE IMPACT OF THE TEMPORAL TREND IN THE VALUATION OF LAND PROPERTY
}

\author{
Monika Maleta, M.Sc. \\ Department Of Civil Engineering And Geodesy \\ Military University Of Technology \\ e-mail:mmaleta@wp.pl
}

\begin{abstract}
The presented case study is to provide various methods of determining the impact of the time trend on the changes in transaction prices of undeveloped land properties. The basis for each property valuation is an analysis of the local market, where the valued property is located. This analysis lies in the implementation of activities related to determining the trend of changes in the prices of real estate and their update on the valuation date, as well as in determining the impact of the various attributes of a property on the formation of a unit transaction price. The valuer making a valuation of a property is required to take into account the changes in price which occur as a result of the passage of time. The price adjustment is done properly if all the changes in price during a certain period of time are taken into consideration. In order to determine the trend of transaction prices, one can use:

- a method of comparing property prices by similar pairs,

- linear and nonlinear additive models,

- nonlinear multiplicative models (e.g., in the form of a multiplicative exponential function, power).

The choice of the right method of updating transaction prices depends on the sample size adopted for the analysis of the real estate market. It is also crucial to select the right representative real estate database that best reflects the tested reality.

A practical and theoretical research method of the time trend was developed using undeveloped land property price data. An analysis of determining the impact of time on real estate prices has been presented using each of the above mentioned mathematical models.

The object of the study was the local market of undeveloped land properties, including sale and purchase transactions conducted in Stoczek Łukowski. A merit analysis of the methods used and a comparison of the obtained results have also been provided.
\end{abstract}

Keywords: time trend, property data base, math models.

JEL Classification: R15.

Citation: Maleta M., (2013), "Methods for Determining the Impact of the Trend in the Valuation of Land Property", Real Estate Management and Valuation, vol. 21, no. 2, pp. 29-36.

DOI: $10.2478 /$ remav-2013-0014.

\section{Introduction}

The purpose behind the analysis of transaction prices on the property market in order to determine the impact of the time trend is to build a model based on one independent variable - time. The consequence of this approach is the omission of all other aspects of the property which are assumed to be included in the price of real estate. Such form of a model is simple and easy to interpret, however, it may take different forms depending on the dynamics of the real estate market during the relevant time period. In order to determine the effect of the time trend, a representative data base of real estate 
transactions should be gathered and, based on this information, almost identical or very similar attributes in a given sample should be identified. The proper analysis of a local market on which property is valued can reveal a group of similar properties which, due to their characteristics and along with an appropriate sample size, will provide the best update on transaction prices on the date of the valuation. The importance of the time trend is critical to the accuracy of valuations carried out on local markets where transaction price growth is significantly noticeable or very large. In this case, the adjustment of transaction prices is necessary and must be executed with due diligence. If transformations of real estate prices are made based on the existing tendencies of a certain local market, the existing trend must be determined.

In the present work, a few different methods were applied to determine the time trend. One of them was a method of comparing property prices by similar pairs and analytical methods of least squares (LS). The descriptions and derivation of formulas used in the different types of models have been omitted, as they have been widely discussed in many textbooks on mathematical statistics and in a number of publications concerning valuation (ADAMCZEWSKI 2011, BARAŃSKA 2008, CZAJA 2001, ŹRÓBEK 2001). The focus is mainly on substantive and practical considerations regarding the methods used. The statistical methods applied in valuation have also been discussed by numerous authors (BITNER 2007, 2010, CELLMER 1999, HOZER et al. 2002, SAWIŁOW 2010).

PAWLUKOWICZ (2009) proposes updating the transaction price only after making adjustments for characteristics other than time. In this paper, a reverse order of operations was adopted. The considered algorithms of price changes are based on the principle that transaction prices are updated on the date that the valuation is carried out, as the first step in the analysis of the real estate market. Therefore, all the tested transaction prices are not adjusted for the impact of various other attributes of the property. Such a sequence of steps performed in the price transformation process on the valuation date was used by the authors of the present research. The impact of real estate characteristics on explaining aspects of transaction price changes over time was omitted and is not the subject of analyses undertaken within this study.

\section{Methods of time trend}

This paper is a theoretical study to determine the best model function of the temporal trend. The issue of price changes over time and the analysis of this phenomenon have been repeatedly discussed in previous publications. A variety of research methods have been discussed by authors of other publications, including the analysis of linear regression (BITNER 2001), the analysis of linear regression and polynomial and neural networks (BUDZYŃSKI 2010) and methods of linear and polynomial regression (BARAŃSKA 2004). The adjustment of transaction prices for the time trend has also been mentioned in several studies (ADAMCZEWSKI 2011, BARAŃSKA 2002, CZAJA 2001, ŹRÓBEK 2007) and textbooks on the valuation of property. A temporal trend in valuation is a tendency that shows the general direction of the phenomena, that is changes in the level of transaction prices and the analysis of these changes over the course of time. The phenomenon of changes in the price level over time assumes various functional forms. A trend is a sequence of observations related to transaction prices in subsequent units of time. Depending on the adopted function, a corresponding regression model can be considered. The trend can be dynamic or static. In the case of a static trend, adjustments to transaction prices are not made and time is treated as another attribute of the property. When dynamic trends are considered, there are several kinds that have been presented in the following table.

Table 1

Classification of an analytical trend model

\begin{tabular}{|c|c|c|c|}
\hline linear & multilinear & $\begin{array}{c}\text { nonlinear reducible } \\
\text { to linear models }\end{array}$ & $\begin{array}{c}\text { nonlinear } \\
\text { irreducible to linear } \\
\text { models }\end{array}$ \\
\hline
\end{tabular}

Source: own work

Nonlinear trend models which are irreducible to the linear form will not be explored in this work. The choice of methods to determine the impact of the trend depends on the sample size adopted for analysis (PRYSTUPA 2001) as well as on the dynamics of the increase in prices over a specified period of 
time. A properly performed market analysis of the trend means that the effect of time is corrected and all transactions are treated as if they were made in one day.

If a database consisting of a dozen or so similar properties is used, the most common method is that of correcting real estate prices by comparing similar pairs. This method is used to compare pairs of the same properties. The adopted properties differ only by the date of the transaction. On this basis, the rate of price changes in the considered time period can be established (ŹRÓBEK 2001). Based on the price rate changes of individual pairs of similar properties, the overall rate of price change is calculated after which the market price at the date of valuation is corrected.

When choosing real estate for a time trend analysis in which the sale and purchase transactions were concluded within a short period of time, we can assume that the price rate change was not too violent and build a linear function model (ŹRÓBEK 2007, CZAJA 2001). When dealing with a database consisting of not a few but dozens of similar real estate transactions, price updates are made using mathematical models. These may include additive models which are characterized by more or less constant fluctuations in the variable, that is the transaction price within a specified period of time. An example is the method of univariate linear regression. In univariate regression analysis, a model consists of a straight line, which can be described by the equation of a regression line. The revaluation of transaction prices on the valuation date is performed by adding a base, calculated from the rate of changes in prices and the time in months that has elapsed since the date the transaction took place to the date of valuation, to the transaction price of a representative patch.

If the rate of the price change in the analysed local market is not uniform and periods of rapid changes, declines or price increases occur in longer time intervals, a function consisting of several regression folding functions is applied to analyze the trend. The linear spline function forms a broken line; it is a multiline trend. When price changes due to the passage of time, it becomes a broken line and in shorter periods of time we can specify linear segments of the phenomena as changes in the transaction prices with distinct points of collapse. If changes in the level and sometimes in the tendency of transaction prices occur at these points, referred to as nodal points, the description of a trend is created by a function which is an approximate straight line equation that consists of a number of regression lines of the common nodes of the so-called moments in time. Basis spline functions must possess the ability to approximate prices to local conditions. The correction of transaction prices on the valuation date is done by adding, to the unit price calculated from the equation model on the date of valuation, the deviation expressing the difference between the transaction price and the price of a representative base model, calculated on the date of the transaction.

In the case of price changes during the analyzed period clearly showing a nonlinear nature, the time trend is defined by a nonlinear regression model. Function logarithmic models and multiplicative models (BARAŃSKA 2010) are used for this purpose. A multiplicative model is characterized by maintaining proportions as to the scale of the periodic fluctuations. A form of the multiplicative exponential function and power is most commonly used in such analysis. In order to estimate the temporal trend, a model consisting of the independent variable of time is built. The correction of transaction prices on the valuation date is carried out as in multiline models.

\section{Comparative analysis of the results of different methods of price updating}

\subsection{Area and applied research methods}

Different methods of analyzing the impact of the temporal trend based on the above discussed models have been presented in the thesis. The analysis pertains to the real estate market of undeveloped land properties within the town of Stoczek Łukowski. Stoczek Łukowski is located in the north-west part of the Łukowski district, in the Lubelskie voivodship, upon the Świder River. It is located approximately $85 \mathrm{~km}$ away from Warsaw, $100 \mathrm{~km}$ from Lublin, and $29 \mathrm{~km}$ from Łuków. The town is surrounded by land forming a rural municipality. The location of Stoczek Łukowski has been presented in figure 1. 


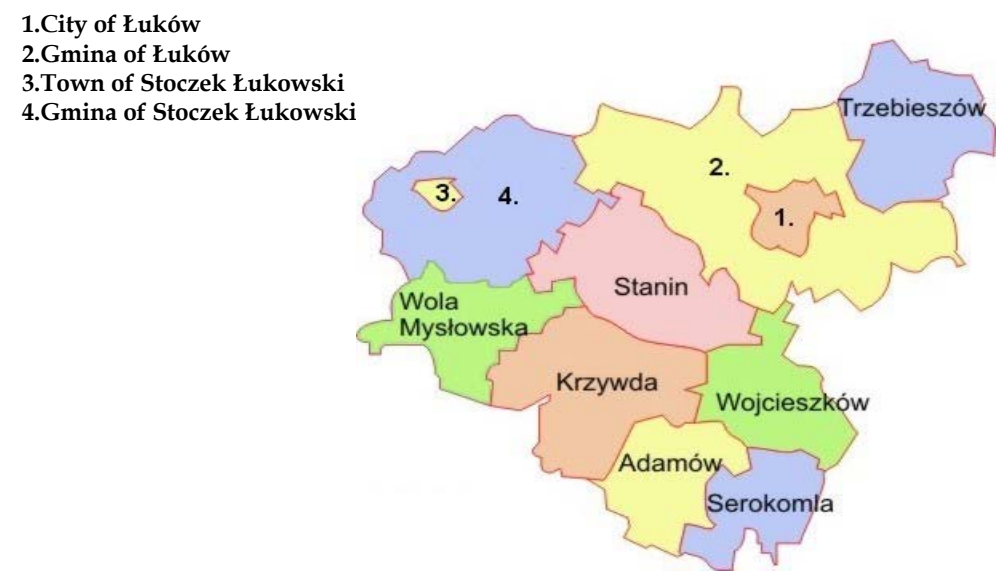

Fig. 1. Location of Stoczek Łukowski. Source: Thesis "Using lands and buildings record data to description of thematic maps" K. Kania.

The research was conducted based on information included in the registry of prices and real estate values. Record data for the town of Stoczek Łukowski was gained from the District Geodesic and Cartographic Documentation Center in Łuków. The data base, which contains 180 undeveloped land properties, was verified in terms of its usefulness to trend listing. Transactions in which the land properties were based on perpetual usufruct or joined perpetual usufruct, as well as parcels which were zoned for construction, were removed from the data base. No other deletions were made. This was because the authors recognize that every single transaction provides information and influences the behaviour of the local market. Finally, a representative base, based on 149 unit prices, was created. The temporal trend was researched for transaction prices from September 2002 until May 2012. The number of transactions in the representative property data base and average price of $1 \mathrm{sq} \mathrm{m}$ in the particular years have been presented in table 2 .

Table 2

The number of transactions and average prices in $2002-2012$

\begin{tabular}{ccc}
\hline Year & $\begin{array}{c}\text { The number of } \\
\text { transactions }\end{array}$ & $\begin{array}{c}\text { Price } \\
\text { PLN/m }\end{array}$ \\
\hline 2002 & 8 & 21.15 \\
\hline 2003 & 12 & 30.45 \\
\hline 2004 & 13 & 31.27 \\
\hline 2005 & 14 & 35.63 \\
\hline 2006 & 23 & 37.32 \\
\hline 2007 & 19 & 40.71 \\
\hline 2008 & 18 & 47.51 \\
\hline 2009 & 13 & 52.12 \\
\hline 2010 & 9 & 58.13 \\
\hline 2011 & 16 & 56.59 \\
\hline 2012 & 4 & 68.37 \\
\hline
\end{tabular}

Source: own work

Prices in this period of time ranged from $14.68 \mathrm{z} / \mathrm{m}^{2}$ to $74.24 \mathrm{z} / \mathrm{m}^{2}$. September 2002 was established as the "zero" month - $\mathrm{T}_{0}$. Calculations were based on a group of commonly available spreadsheet functions in Microsoft Excel. Based on the method of comparing prices of similar pairs of properties, a trend of price changes (given as percentages) was established. Ten pairs of transactions, for which the described properties have identical features, were selected from the representative base. The algorithm of the most similar property choices was deterministic because it was based on the similarity of property quality criteria and, therefore, on the scaled attributes. The selected similar land 
properties differed only in terms of the time of the transaction and thus, helped to define the existing time trend. Price change coefficients were defined for the 10 chosen pairs. Monthly trends of price changes as well as an annual trend were calculated as an arithmetic average from unit coefficients.

Additive and multiplicative mathematical models were also constructed for trends in the analyzed time period of 2002-2012. Models were constructed based on time, which was the sole independent variable, and were solved by the least squares method. In all analyzed methods, the correlation coefficient, which informs us about the strength of the linear connection between the dependent variable (price) and explanatory variable (time), was established. The advantage of the correlation coefficient is that, in addition to correlation strength, it also indicates the direction (positive or negative). Values of the coefficient from 0.6 to 0.9 are evidence supporting a strong correlation (CZAJA, LIGAS 2010) between price and time. The determination coefficient $R^{2}$, which is the most commonly used as a measure of the degree of linear fit, was used for statistic evaluation. In order to determine the dynamics of price changes, an additive linear model was constructed. In the univariate linear regression, the regression coefficient or the slope of the tangent line constitutes a coefficient of the price change. It determines the expected price change in the accepted unit of time - one month. The time shift was set with respect to the transaction which is the earliest in the $T_{0}$ base. The study also used the multilinear trend model.

In the representative property base for 2002 - 2012, two time periods in which we can talk about changing trends in real estate prices were distinguished. These periods were from September 2012 to November 2006 and from December 2006 to May 2012. In those periods, one can notice a significant change in the level of transaction prices. Based on that, one point set in November 2006, for which the time period $T_{1}$ is 51 , was chosen. At that point, two functions of the regression line are combined. The functions form a general equation of a broken line, which approximates the whole tested period. The model-building algorithm was based on adding additional basic functions which were created for the considered time intervals. In the separate time periods, records were made for all the individual transaction prices and compiled into one system of equations. Based on this system of equations, a broken regression model was set. This relationship is presented below by a chart of transaction price changes in the subsequent months.

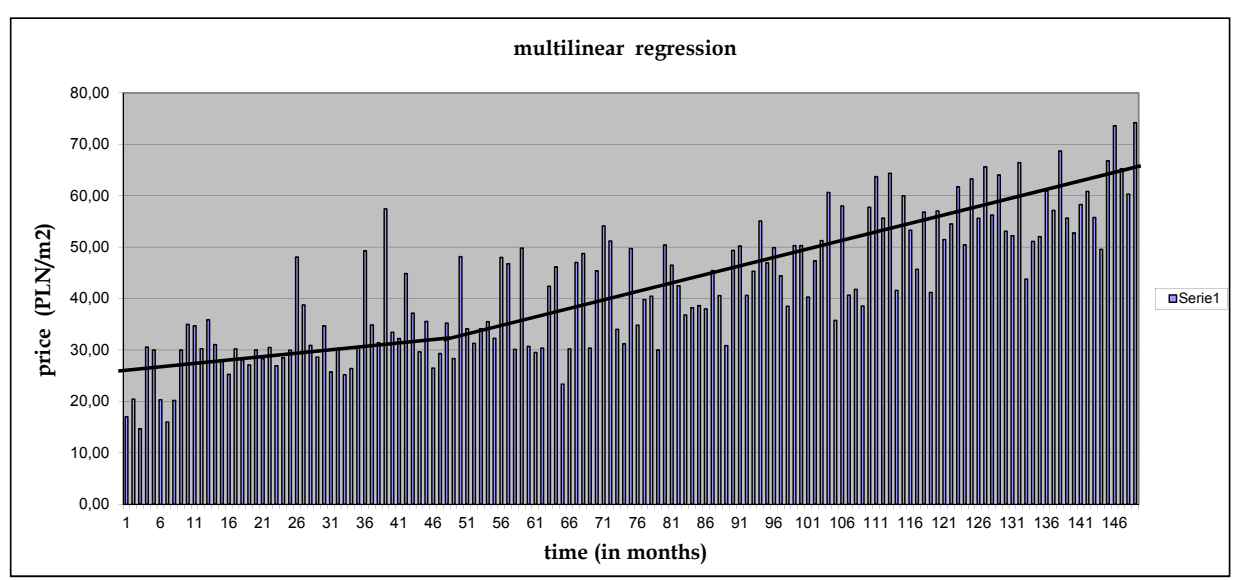

Fig. 2. Trend line for multilinear regression. Source: own work

In order to determine the trend, an additive logarithmic model was also constructed. In addition, changes in the price level over time were specified by the nonlinear functions of multiplicative models. The estimation of model parameters was carried out after each linearization of nonlinear equations. After the operation of importing nonlinear models into a linear one, the equations of the exponential and power series models were established.

\subsection{Obtained results}

The method of comparing property prices by similar pairs

The monthly trend of price changes and the annual trend amounted to $2.08 \%$ and $24.94 \%$ respectively. These figures are presented in the table below: 
Price change coefficients for the model of comparing properties in pairs.

\begin{tabular}{|c|c|c|c|c|c|c|c|c|c|c|}
\hline \multirow{2}{*}{$\begin{array}{l}\text { price change } \\
\text { coefficients in } \\
\text { individual pairs }\end{array}$} & 1 & 2 & 3 & 4 & 5 & 6 & 7 & 8 & 9 & 10 \\
\hline & $\begin{array}{l}\stackrel{F}{F} \\
\stackrel{\infty}{+} \\
\stackrel{+}{+}\end{array}$ & $\begin{array}{l}\text { त్ర } \\
\text { กุ. } \\
0\end{array}$ & 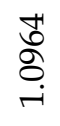 & $\begin{array}{l}\infty \\
\infty \\
10 \\
\end{array}$ & $\begin{array}{l}\stackrel{0}{0} \\
\stackrel{0}{\infty} \\
\dot{0}\end{array}$ & $\begin{array}{l}\stackrel{g}{F} \\
\stackrel{0}{0} \\
\dot{0}\end{array}$ & 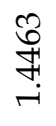 & $\begin{array}{l}+1 \\
\infty \\
\infty \\
\infty \\
\dot{c}\end{array}$ & 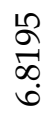 & 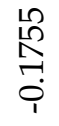 \\
\hline $\begin{array}{l}\text { overall price change } \\
\text { coefficients within a } \\
\text { month }\end{array}$ & \multicolumn{10}{|c|}{$2.08 \%$} \\
\hline $\begin{array}{l}\text { overall price change } \\
\text { coefficients within a } \\
\text { year }\end{array}$ & \multicolumn{10}{|c|}{$24.94 \%$} \\
\hline
\end{tabular}

Source: own work

The method of linear regression

The obtained equation takes the form of $\mathrm{C}=23.25+0.33 \mathrm{t}$. The designated slope of a straight line is 0.33 , signifying that the change in real estate prices in a month is $0.33 \mathrm{PLN} / \mathrm{m}^{2}$. The regression coefficient is positive, which signifies a price increase in the subsequent months. This tendency is confirmed by the calculated correlation coefficient, which was established as 0.81968 . The correlation coefficient indicates the direction of a linear relationship. In this case, the price dependence in correlation to time tends to increase. The coefficient of determination $\mathrm{R}^{2}$ calculated for the linear regression was 0.67188 , which means that $67.19 \%$ of transaction price volatility is explained by the influence of time. It can be concluded that a well-established feature describes the existing time trend, since the whole period is characterized by a slow rise in prices.

The method of multiline regression

The polygonal model was defined as $C=25.06+0.27\left(\mathrm{~T}_{1}-\mathrm{T}_{0}\right)+0.38\left(\mathrm{t}-\mathrm{T}_{1}\right)$, where $\mathrm{t}$ - the time in months elapsed from the specific date of a transaction to September 2002, within the time period of December 2006 to May 2012. This equation tells us that transaction prices rose by $0.27 \mathrm{z} / / \mathrm{m}^{2}$ per month for the first time between September 2002 and November 2006, and again in the period from December 2006 to May 2012 during which time the price growth rate was found to be higher at $0.38 \mathrm{z} / \mathrm{m}^{2}$ per month. In both time periods, the established tendency was shown to be increasing with a significantly greater increase in prices in the second identified period of time. After establishing the final form of the multiline regression model, an assessment was made by calculating the coefficients of determination. This ratio had a value of $\mathrm{R}^{2}=0.67715$, which means that the designated model explains $67.72 \%$ of transaction price changes by variation in transaction time. This value is very close to that established by means of the univariate linear regression. The values of correlation coefficients for price change indicators are 0.63966 and 0.77142 . They define a strong increasing correlation of transaction prices, relative to the time of the transaction. These figures confirm the upward trend determined by the price change coefficients in the broken line regression equation.

\section{The method of logarithmic regression}

The obtained logarithmic model takes the form of $C=8.20+9.11 \times \ln (t)$. The value coefficients in this model can be interpreted as follows: if the time logarithm increases by one month, the average transaction price will increase by $9.11 \mathrm{PLN} / \mathrm{m}^{2}$. The coefficient of determination $\mathrm{R}^{2}$ calculated for the logarithmic regression was 0.46073 . We can say that transaction price volatility is in $46.07 \%$ explained by the influence of the natural logarithm of the trend.

The method of nonlinear multiplicative functions

The multiplicative nonlinear functions developed for the study of the local land market assumed the the following forms:

- exponential $C=\exp (3.22+0.01 \times t)$,

- power $\quad C=\exp (2.81+0.24 \times \ln (t))$. 
The values of the following regression coefficients in these models can be interpreted as follows:

- exponential, in the accepted unit of time of one month, there is an increase in the natural logarithm of the transaction prices by an average of $0.01 \mathrm{PLN} / \mathrm{m}^{2}$,

- power series, the increase in the natural logarithm in the time period of one month results in an increase of the natural logarithm of real estate prices by an average of $0.24 \mathrm{PLN} / \mathrm{m}^{2}$,

The values of determination coefficients $\mathrm{R}^{2}$ for the above listed nonlinear models were respectively: 0.66242 and 0.52373 . In the case of the exponential model, this means that the variation of the natural transaction price logarithm is $66.24 \%$ explained by the influence of the temporal trend. For the power series model, $52.37 \%$ of the variability of the natural logarithm of land transaction prices is explained by the influence of the natural logarithm of time.

As seen from the above results, the best model was a curved exponential model with the highest coefficient of determination, and the land logarithmic model, which prevails in the market, with the lowest value of the $\mathrm{R}^{2}$ coefficient, least determined by the trend. The correlation coefficients for these models were: $0.81389,0.72369$, and 0.67877 , and inform us of a positive rate of change in transaction prices over time. For the exponential model, there is a strong correlation and significant linear relationship between the natural logarithm of the transaction price and the time of the transaction.

A comparison of all calculated determination coefficients for each of the trends has been presented in the table below. The model of a multilinear trend with the highest $\mathrm{R}^{2}$ reveals the best of the analyzed functions defined on the basis of a representative sample in the accepted study period. The model of a linear trend is also characterized by a similar value although, in its case, the models of multiplicative functions were proven to be somewhat weaker. The accuracy of the exponential coefficient of determination is close to that of the linear and multilinear regression models, and is a good reflection of reality. The worst trends to determine the change in real estate prices as a result of the passage of time are the power and logarithmic trends, as demonstrated by the lowest $\mathrm{R}^{2}$ coefficient.

Table 4

List of the coefficients of determination for the analyzed types of mathematical models

\begin{tabular}{cccccc}
\hline $\begin{array}{c}\text { Trend } \\
\text { type }\end{array}$ & $\begin{array}{c}\text { Linear } \\
\text { trend }\end{array}$ & $\begin{array}{c}\text { Multilinear } \\
\text { trend }\end{array}$ & $\begin{array}{c}\text { Exponential } \\
\text { trend }\end{array}$ & $\begin{array}{c}\text { Power } \\
\text { trend }\end{array}$ & $\begin{array}{c}\text { Logarithmic } \\
\text { trend }\end{array}$ \\
\hline $\mathbf{R}^{2}$ Value & 0.67188 & 0.67715 & 0.66242 & 0.52373 & 0.46073 \\
\hline
\end{tabular}

Source: own work

\section{Summary and conclusions}

The aim of the presented research was the analysis of methods defining the temporal trend. As commonly known, the land property market is an area of great variation. This is seen in the level of prices changes within each period. Since trend research is quite a complicated function, it is difficult to develop a model that can be trusted. It is also not easy to update prices based on regression models and especially multiline methods. Achieving the best results requires thorough analysis and a sound knowledge of the relations in the local real estate market. Defining a trend based on the presented statistical methods introduces a lot of objectivity and can be used for both individual as well as massive, comprehensive valuation.

The database of representative undeveloped land properties analyzed in the thesis referred to transactions carried out at different times. Thus, there was a need to test how well they represent reality by various mathematical models. All the designated trends in the thesis showed an increase in prices in the relevant time frame. The $\mathrm{R}^{2}$ coefficient was adopted as an accuracy criterion of the models. The most reliable models of predicting the trend and determining price adjustments due to changes in transaction prices were characterized by coefficient values of no less than 0.60 . The multilinear, linear and exponential regression models fulfilled this condition. The functions determined based on these methods fit well into the set of transaction prices, value $R^{2}>0.60$. These models can be used to describe and research the dependence of prices on time in a large number of transactions, even in intervals of several years. This cannot be said of the other methods, which did not prove to be effective in determining the time trend, $R^{2}<0.60$. Similar results were obtained in the 
research of another author (BARAŃSKA 2010), where as far as accuracy was concerned, the prediction model was found to be better than the exponential power one.

The issue of updating prices on the valuation date had also been discussed in a case study (BUDZYŃSKI 2010), where an advanced method of artificial neural networks proved to be more accurate than the analyzed polynomial and linear models. At the same time, it should be noted that these conclusions were drawn on the basis of a "narrow" local real estate market, with the coefficient of determination accepted as the criterion of selecting functions. If the estimated models are given a detailed statistical review and reserach is conducted on more diversified real estate markets, different conclusions may be reached, which is the possible subject of further analyses.

\section{Bibliography}

ADAMCZEWSKI Z., 2011, Elementy modelowania matematycznego w wycenie nieruchomości. Podejście porównawcze, Oficyna Wydawnicza Politechniki Warszawskiej, Warszawa.

BARAŃSKA A., 2002, Kryteria stosowania modeli stochastycznych w predykcji rynkowej wartości nieruchomości, Geodezja, tom 8, zeszyt 1.

BARAŃSKA A., 2004, Analiza w czasie stanu rynku nieruchomości gruntowych na terenie Polski potudniowowschodniej, Geodezja, tom 10, zeszyt 2.

BARAŃSKA A., 2008, Metody jakościowe i ilościowe na ustugach wyceny nieruchomości, Acta Scientarium Polonarium Geodesia et Descriptio Terrarum, 7(2).

BARAŃSKA A., 2010, Modele multiplikatywne w procesie wyceny nieruchomości, Studia i Materiały Towarzystwa Naukowego Nieruchomości, Olsztyn - vol. 18, nr 1.

BITNER A., 2001, Sprowadzanie cen na określoną datę, Świat Nieruchomości nr 53.

BITNER A., 2007, Konstrukcja modelu regresji wielorakiej przy wycenie nieruchomości. Acta Scientarium Polonarium Administratio Locorum, 6(4).

BITNER A., 2010, O użyteczności metod statystycznych w wycenie nieruchomości. Polska Akademia Nauk, Kraków, Komisja Technicznej Infrastruktury Wsi, nr 12.

BUDZYŃSKI T., 2010, Metodyka aktualizacji cen na przykładzie nieruchomości lokalowych, Studia i Materiały Towarzystwa Naukowego Nieruchomości, Olsztyn - vol. 18, nr 1.

CELLMER R., 1999, Propozycja procedury wyceny nieruchomości metoda analizy statystycznej rynku, Wycena Nr 6 (47).

CZAJA J., 2001, Metody szacowania wartości rynkowej i katastralnej nieruchomości, Komp - System, Kraków.

CZAJA J., LIGAS M., 2010, Zaawansowane metody analizy statystycznej rynku nieruchomości, Studia i Materiały Towarzystwa Naukowego Nieruchomości, Olsztyn - vol. $18 \mathrm{nr} 1$.

HOZER J., KOKOT S., KUŹMIŃSKI W., 2002, Metody analizy statystycznej rynku w wycenie nieruchomości, Warszawa, PFSRM.

KANIA K., 2012, Wykorzystanie danych ewidencji gruntów i budynków do opracowania map tematycznych, Praca dyplomowa, WIG WAT, Warszawa.

PAWLUKOWICZ R., 2009, Metoda porównywania parami z wykorzystaniem statystyczno-ekonometrycznego modelowania zmian cen $w$ czasie, Studia i Materiały Towarzystwa Naukowego Nieruchomości, Olsztyn - vol. $17 \mathrm{nr} 1$.

PRYSTUPA M., 2001, Wycena nieruchomości przy zastosowaniu podejścia porównawczego, PFSRzM, Warszawa.

SAWIŁOW E., 2010, Problematyka określania nieruchomości metoda analizy statystycznej rynku. Studia i Materiały Towarzystwa Naukowego Nieruchomości, Olsztyn - vol. 18, nr 1.

ŹRÓBEK S., 2001, Wycena wartości rynkowej nieruchomości, Wydawnictwo UWM, Olsztyn.

ŹRÓBEK S., 2007, Metodyka określania wartości rynkowej nieruchomości, Wydawnictwo UWM, Olsztyn. 